\title{
A Fit between Logistics and Supply Chain Management Education and Jobs Market Need in Nepal
}

\author{
Subarna Bir JBR* \\ Umesh Singh Yadav, PhD**
}

DOI: https://doi.org/10.3126/jnbs.v14i1.41489

Received on 11 May 2021

Accepted on 30 October 2021

\begin{abstract}
The purpose of this paper is to explore a fit between Logistics and Supply Chain Management (LSCM) related course content and the industry needs in the Nepalese context. Since this study is undertaken using the Nepalese sample, the knowledge and skills prioritized by employers, it can be of value to educators while designing their LSCM course content. Desk-based research involving content analyses was done to understand the supply side information i.e. relative coverage of LSCM topics in business-related courses and degrees offered at selected five Nepalese Universities and for the demand side information i.e. analysis of job description of the LSCM related vacancies in the Nepalese job market over eighteen weeks. The study reveals that the inclusion of LSCM courses in the business programs at Nepalese Universities is currently negligible as none of them offered a separate program dedicated to LSCM. Besides, the LSCM courses were limited to just one course per program weighing not more than three credit hours. Instead, there seems to be an unprecedented number of business schools and colleges leaning towards more sellable traditional business degrees related to finance, marketing, human resource management, IT, and hospitality. Finally, when comparing the relative coverage of LSCM topics in the curriculum to the relative demand for such knowledge by the employers, there seems to be an over-emphasis or under-emphasis of courses related to LSCM both at the bachelors and masters level indicating a mismatch between the expectations of employers and education offered by the universities.
\end{abstract}

Keywords: Emphasis, job market fit, LSCM

\section{INTRODUCTION}

Logistics and supply chain management (LSCM) as an academic discipline has started to gather increasing attention among students and universities globally in recent decades. It was

\footnotetext{
* Mr. JBR is an Assistant Professor at School of Business, Pokhara University.

Email: suuvrana@gmail.com

** Dr. Yadav is an Associate Professor at School of Business, Pokhara University.

Email: umeshsingh@pusob.edu.np

Corresponding Author: Subarna Bir JBR.
} 
since the 1970s that this discipline gradually began to gain popularity among educating institutions (Lancioni et al., 2001a), however many business schools in the past were often reluctant to accept logistics management as a separate and distinct field (Langley \& Mundy, 1978). A continued and growing interest has become quite evident towards LSCM (Ballou, 2006) and is currently seen as a booing academic program around the globe. Many factors such as the internationalization of the products and businesses, increased purchasing power, and everevolving consumer preferences as well as efforts among countries to promote trade openness at the regional or international level all have necessitated logistics and supply chain management related know-how and professionals.

However, significant studies from the past have indicated that quite often the graduates are not found to be adequately prepared for their careers in LSCM (Murphy \& Poist, 1998; Van Hoek et al., 2002; Myers et al., 2004) while others highlighted the need for educators to pay attention to the widening gap between their LSCM course content and skills requirements of the industry (Wu et al., 2013).

The purpose of this paper is to explore the fit between the LSCM related course content and the industry needs in the Nepalese context. In 2013, the revised curriculum of Bachelor of Business Administration of Pokhara University, Nepal dropped the only one course related to LSCM, previously incorporated in its marketing concentration course in a backdrop where more and more university-level LSCM programs continue to rise in response to industry demand for quality graduates (Gravier \& Farris, 2008). This very event seeded a thought to investigate the whereabouts of LSCM education and the job market in Nepal. Necessarily, it raised two questions: the first was do remaining universities also offer LSCM related courses or not? And the other was whether organizations announce LSCM related job vacancies in Nepal? If they are announced, what knowledge or skills relevant to logistics and supply chain management, employers might be seeking in their potential workforce? It was to be explored.

The study thus resorted to three fundamental objectives: one is to get insights about the LSCM related courses and programs being offered by the universities in Nepal; second, to trace out the kind of logistics and supply chain management related knowledge and the skills set desired by the organizations from the university graduates, and the final objective is to see a fit between the content coverage of LSCM related courses and the expertise desired by the employers for such jobs. Since no research relevant to this study was undertaken using the Nepalese sample, the knowledge and skills prioritized by the employers can be of value to the educators while designing their LSCM course content. Further, this study sets up a stage for further discussion and much-needed empirical investigations currently out of focus from the scholars and educators regionally as well as globally.

The methodology adopted by this paper takes advantage of the availability of up-to-date 'live' data collected from the Internet. As a result, this study provides new insights into the employer demand for LSCM related jobs. The findings of this research could induce further researches on the need for providing higher educations related to LSCM by the Nepalese universities to meet the job market.

\section{LITERATURE REVIEW}

\subsection{LSCM Education Related Findings and Challenges at University Level}

The research works carried out by Johnson and Pyke (2000) carry special importance while studying LSCM related course content and teachings. Johnson and Pyke (2000) identified 12 areas within the supply chain management discipline after a detailed analysis of courses related to supply chain management. The framework for teaching supply chain management developed by Johnson and Pyek (2000) also played a pivotal role for later studies carried out by different 
researchers with time such as in the case of Radovilsky et al.(2007) and Sodhi et al. (2008) among others.

In 2007, Wu found a significant difference among the content of the logistics curriculum when he conducted a detailed analysis on publicly available syllabi from 77 schools with logistics programs, of which the majority belonged to the US. In comparison with other nations, USA was found giving a lot of attention to Information and Technology and Seminar whereas in China the emphasis was to finance area. To note is that his research was limited by the fact that it was collected online without directly approaching the schools and lacked in-depth content analysis of the logistics curricula for which he suggested further research in the future.

Gravier and Farris (2008) presented an in-depth review of 81 journal articles published in 14 journals from the 1960 s to 2000 s and observed some major trends that dealt with the logistics curriculum, content, and pedagogy. Gravier and Farris (2008) stress the need for continued collaboration between the educators and the industry to further logistics education.Cevik et al. (2013)found that the curricula as well as the programs frequently undergo changes and redefine themselves.

Lutz and Birou (2013) carried first of its kind, a large-scale analysis of courses dedicated to logistics at both undergraduate and graduate-level and compared it to the industry needs. Bahouth et. al. (2014) studied SCM courses at an undergraduate level among ten selected universities from the US and they found it hard to get an agreed-upon common curriculum. Sinha et al. (2016) in their study when found a gap between the industry's demand for SCM talent and the educational offerings appealed to higher education intuitions for the revision of their course offerings.

\subsection{Knowledge and Skills Requirements for LSCM Related Jobs}

Gammergaard and Larson (2001) in a study where they surveyed 123 Council for Logistics Management (CLM) members, listed out a set of skills required in logistics and supply chain managers- supply chain awareness, problem-solving ability and teamwork, communication skills, their ability to visualize a bigger picture, critical reasoning and decision making skills, time management and self-discipline, leadership and motivation attributes, change management and cross-functional awareness.

Mangan and Christopher (2005) identified the three key knowledge areas and skills required for logistics and supply chain, namely the general knowledge areas (finance, IT, management), logistics and SCM knowledge areas (operations/SCM, logistics in emerging markets), and skill areas (analytical, interpersonal, leadership and change management) as important in future.

Problem-solving skills, teamwork, decision-making ability, communication skills, and negotiation were deemed important for supply chain professionals by the studies of McCarter et al. (2005). Giunipero et al. (2006) highlighted five key skills of strategic importance required by supply chain professionals: team-building skills, strategic planning skills, communication skills, technical skills, and broader financial skills.

Murphy and Poist in 2007 for a longitudinal assessment on the skills requirements carried out on senior-level logisticians, concluded that management skills were perceived as the most important within the business skills category along with analytical reasoning and problem-solving abilities.

Sodhi et al. (2008) measured the relative coverage of the same supply chain topics in MBA-level supply chain electives and operations management cores course of the top 50 business schools in the US to reveal how they have responded to the employers' needs. Their analysis indicates that supply usually matches demand though there may of undersupply of practice- or 
A Fit between Logistics and Supply Chain Management Education and Jobs Market Need in Nepal

process-oriented topics or an oversupply of conceptual and strategy-oriented topics.

Cacciolatti and Molinera (2013), explore the demand for supply chain management jobs in the UK and found that the most preferred skills in graduates by the employers were analytical skills and the ability to solve problems. All these previous literature formed the basis for a conceptual framework for this study as outlined in Figure 1:

\section{Figure 1}

A Conceptual Framework for the Job Market Fit Between the University Level

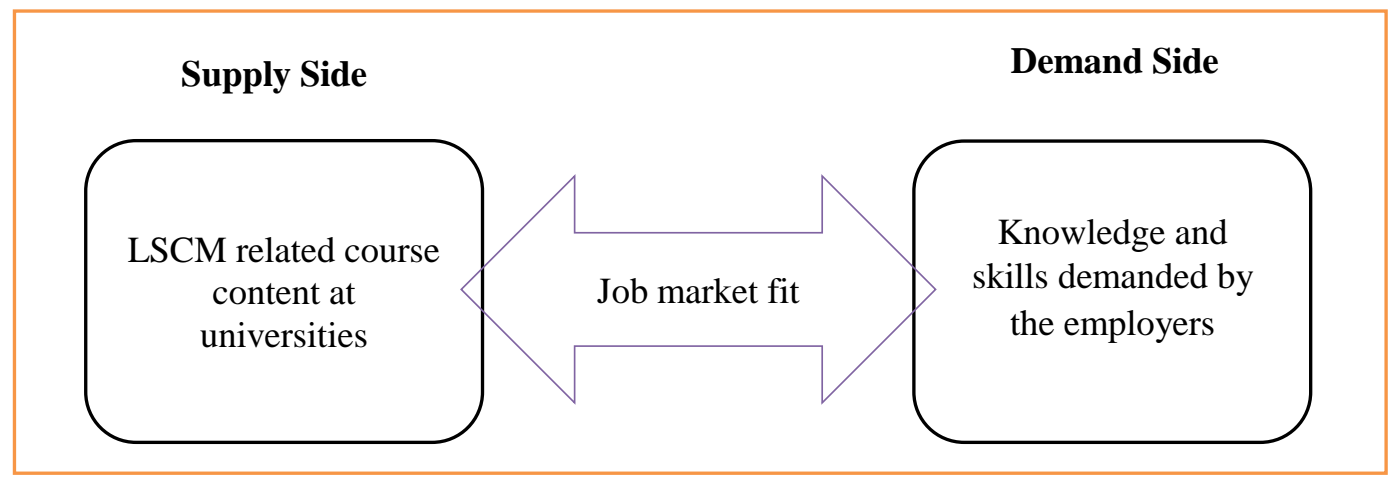

\subsection{LSCM Course Content and Expertise Demanded by the Employers}

The twelve categories determined by Johnson and Pyke (2000) were adopted as it is whereas the broad skills categories determined by Sodhi et al. (2008) were modified to better fit the Nepalese context and to contain within the scope of this study (Table 1).

\section{Table 1}

Categories Related to Supply Chain Management Topics and Broad Skills Adopted for the Study

\begin{tabular}{lll}
\hline Supply chain management topics categories* & \multicolumn{1}{c}{ Broad skills categories** } \\
\hline 1. Location & 1. General analytical ability \\
2. Transportation and logistics & 2. Basic IT \&computing skills \\
3. Inventory and forecasting & 3. Programming and specialized software \\
4. Marketing and channel restructuring & 4. Communication \\
5. Sourcing and supplier management & 5. Project related \\
6. Information and electronic mediated & 6. Statistics \\
7. Product design and new product & 7. Leadership and team management \\
introduction & 8. Other operations management skills \\
8. Service and after sales support & 9. Negotiation skills \\
9. Reverse logistics and green issues & \\
10. Outsourcing and strategic alliances & \\
11. Metrics and incentives & \\
12. Global issues &
\end{tabular}

Note. *Adapted from Johnson and Pyke, 2000. **Adapted from Sodhi et al., 2008. 


\section{DATA AND METHODOLOGY}

Desk-based research involving content analyses was done to understand the supply side information i.e. the relative coverage of LSCM topics in business-related courses and degrees offered at the Nepalese Universities and the demand side information i.e. the analysis of job description of the LSCM related vacancies in the Nepalese job market to get a first-hand perspective of the kind of knowledge and skills sought by the employers in their applicants.

Previous researches have used quantitative as well as qualitative approaches such as surveys, questionnaires, focus groups (Murphy \& Poist, 1994; Gammerlgaard \& Larson, 2001; Myers et al., 2004; Giunipero et al. 2006) to understand the knowledge and skills required in LSCM related jobs and industries. But, content analysis opted for this study with the intention of unraveling the kind of knowledge and skills required for LSCM related jobs based on job postings (Radovilsky et al., 2007) as well as the coverage of such knowledge in the University course curriculum.

All the logistics and supply chain management-related job vacancy advertisements announced through a selected online job portal site constituted the population for this study. To better reflect the present scenario, live data was collected on a day-to-day basis from the job advertisements announced for different positions from August 2019 to November 2019 between a period of eighteen weeks from a national level online job portal site: Merojob.com. Since the portal also sourced vacancy announcements from various print-based national level newspapers, the need for collecting job vacancies from the print media platforms was not required. Only the jobs stationed here in Nepal were considered for the study. Though a total of forty-three vacancy advertisements were announced, only thirty-six of them suited the purpose of the study.

Next, the syllabi of different courses being taught in different programs were either downloaded from the official websites of the sample universities or were accessed via mail or a phone call with the school program coordinators. Currently, in Nepal, there are a total of eleven universities, out of which only five were chosen based on the chronological date of establishment (Table 2).

\section{Table 2}

List of Universities Considered for the Study

\begin{tabular}{lllc}
\hline \multicolumn{2}{l}{ Name of the university } & Location & Date of establishment (A.D.) \\
\hline 1. & Tribhuvan University & Kathmandu & 1959. \\
2. & Nepal Sanskrit University & Dang & 1986 \\
3. & Kathmandu University & Kathmandu & 1991 \\
4. & Purbanchal University & Biratnagar & 1993 \\
5. & Pokhara University & Pokhara & 1997 \\
\hline
\end{tabular}

Only the syllabus of those courses related to LSCM was collected and used for analysis. Other programs or courses that may have otherwise included a minor portion of LSCM related courses were excluded from the study even if they were under the same faculty. In addition, fouryear bachelor's programs and two-year master's programs related to business were only considered for the study and excluded one-year post-graduate programs. Besides, two more exclusions were also made: first the operation and/or production management courses, though 
A Fit between Logistics and Supply Chain Management Education and Jobs Market Need in Nepal

closely related to LSCM, were also not taken into the study; second, this study refrained itself from analyzing that portion of LSCM related course syllabus that contained topics or chapters related to other disciplines. For instance, a total of 16 lecture hours of topics related to IT Entrepreneurship in the syllabus of IT Entrepreneurship and Supply Chain Management course from the curriculum of Bachelor in Information Management (BIM), Tribhuvan University were excluded from the analysis. These attempts were made for the sole purpose of ensuring homogeneity in the nature and the essence of programs being examined.

Table 3

Different Business Related Programs Offered by the Universities

\begin{tabular}{|c|c|c|c|}
\hline $\begin{array}{l}\text { S. } \\
\text { No }\end{array}$ & & Bachelor's Program & Master's Program \\
\hline 1. & $\begin{array}{l}\text { Tribhuvan } \\
\text { University }\end{array}$ & $\begin{array}{ll}\text { 1. } & \begin{array}{l}\text { Bachelor of Business Studies } \\
\text { (BBS) }\end{array} \\
\text { 2. } & \begin{array}{l}\text { Bachelor of Business } \\
\text { Administration (BBA) } \\
\text { 3. }\end{array} \\
\text { Bachelor of Information } \\
\text { Management (BIM) } \\
\text { 4. } \begin{array}{l}\text { Bachelor of Travel and } \\
\text { Tourism Management (BTTM) } \\
\text { 5. }\end{array} \\
\begin{array}{l}\text { Bachelor of Hotel Management } \\
\text { (BHM) }\end{array} \\
\text { 6. } \begin{array}{l}\text { Bachelor of Business } \\
\text { Management (BBM) }\end{array}\end{array}$ & 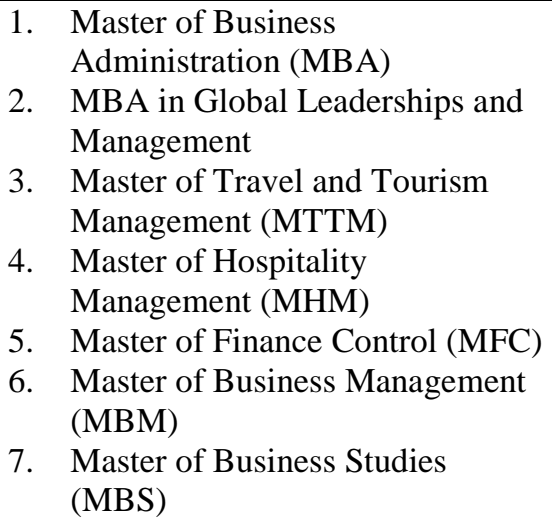 \\
\hline
\end{tabular}

\begin{tabular}{|c|c|c|c|}
\hline 2. & $\begin{array}{l}\text { Nepal } \\
\text { Sanskrit } \\
\text { University }\end{array}$ & None & None \\
\hline 3. & $\begin{array}{l}\text { Kathmandu } \\
\text { University }\end{array}$ & $\begin{array}{ll}\text { 1. } & \text { Bachelor of Business } \\
\text { Administration - BBA } \\
\text { (Emphasis) } \\
\text { 2. } \\
\text { 3BA (Honors) } \\
\text { Bachelor of Business } \\
\text { Information System (BBIS) } \\
\text { 4. } \begin{array}{l}\text { Bachelor of Hospitality and } \\
\text { Tourism Management } \\
\text { (BHTM) }\end{array} \\
\end{array}$ & $\begin{array}{ll}\text { 1. } & \text { Masters of Business } \\
\text { Administration (MBA) } \\
\text { 2. }\end{array}$ \\
\hline 4. & $\begin{array}{l}\text { Purbanchal } \\
\text { University }\end{array}$ & $\begin{array}{l}\text { Bachelor of Business } \\
\text { Administration (BBA) }\end{array}$ & $\begin{array}{ll}\text { 1. } & \text { Master of Business } \\
& \text { Administration (MBA) }\end{array}$ \\
\hline 5. & $\begin{array}{l}\text { Pokhara } \\
\text { University }\end{array}$ & $\begin{array}{ll}\text { 1. } & \text { Bachelor of Business } \\
\text { Administration (BBA), } \\
\text { 2. BBA in Banking and Insurance } \\
\text { 3. BBA in Travel and Tourism } \\
\text { 4. Bachelor of Computer } \\
\text { Information System (BCIS) } \\
\text { 5. Bachelor of Hotel Management } \\
\text { (BHM) } \\
\text { 6. Bachelor in Health Care } \\
\text { Management (BHCM) }\end{array}$ & $\begin{array}{ll}\text { 1. } & \text { Master of Business } \\
\text { 2dministration (MBA) } \\
\text { 2. MBA in Finance } \\
\text { 3. } \text { MBA in Global Business } \\
\text { 4. MBA (Executive) } \\
\text { 5. Master of Computer Information } \\
\text { System (MCIS) } \\
\text { 6. Master of Health Care } \\
\text { Management (MHCM) }\end{array}$ \\
\hline
\end{tabular}


Table 3 reveals the different programs being taught at the bachelor's and master's levels in Nepal. Tribhuvan University offers the most diverse range of programs related to business and management whereas Nepal Sanskrit University has no programs related to business or management. Since the data required for the study consisted of text both in vacancy advertisements and course syllabi, content analysis was used. Content analysis is a research technique where replicable and valid inferences from a text are made to the contexts of their use (Krippendorff, 2004). In the content analysis technique, the occurrence of the relevant words and phrases from the text of job advertisements were analyzed. The content analysis was carried out manually to avoid possible inconsistent terminologies and understand the implied meaning of contents in the job descriptions for proper categorization.

To carry out the content analysis of both the job advertisements as well as the syllabi of LSCM related courses, identifying the different areas broadly incorporated in the logistics and supply chain management sector was first required. Therefore, the categorization scale developed by Johnson and Pyke (2000) and Sodhi et. Al. (2008) served as a basis for the categorization of the keywords both from the text of the job advertisements as well as from course syllabi. After a detailed literature review new categories, negotiation skills, for instance, were also added to the existing categories to make them more inclusive. Kovács et al. (2012) recognized negotiation as one of the supply chain skills (as cited in Jordan \& Bak, 2016).

To know the relative coverage of the SCM-related topics in the course descriptions of different programs, the content of the syllabus was thoroughly read and every time a supply chain topic relevant to a particular category was noticed point "1" was assigned to that category. The total point of each category column indicated the proportion of courses covering that particular topic.

Similarly, the content analysis of the job advertisement was also carried out to reveal the proportion of job ads requiring specific categories in both skills set and knowledge set. Each of the vacancy announcements collected from the job portal was segregated into two segments: the job specification segment mentioned the necessary skills and the job description segment detailed the relevant knowledge and competencies in the required position.

To ensure the validity of the study being conducted, the study primarily adopted the processes suggested by Potter and Donnerstein (1999). According to these authors, determining validity in content analysis requires a two-step process: first, the researcher must design a coding scheme that is often guided by an existing theory that lays out variable, their definitions, their values, and rules for recognizing these variables in the content being coded. Next, the coding decisions made by the coders are to be compared against some standard. If the codes match the standard, the coding is regarded as producing a valid outcome. Therefore, this research has adapted the categories developed by Johnson and Pyke (2000) and Sodhi et al. (2008) as a standard for the coding required to establish the validity of the data.

To ensure reliability, stability, and reproducibility testing was carried out as suggested by Krippendroff (2004). Therefore, firstly the text was coded before and after the data analysis phase (i.e. a time-lapse was created) to maintain the stability of the findings. Secondly, the mentor assigned for this study also carried out the coding process independently by selecting an arbitrary number of job advertisements as well as the university syllabus from the pool to ensure consistent findings were reproduced while using the same coding patterns. A systematic process adopted for this study is pictorially represented in Figure 2. 
Figure 2

Flowchart for the Process of Content Analysis

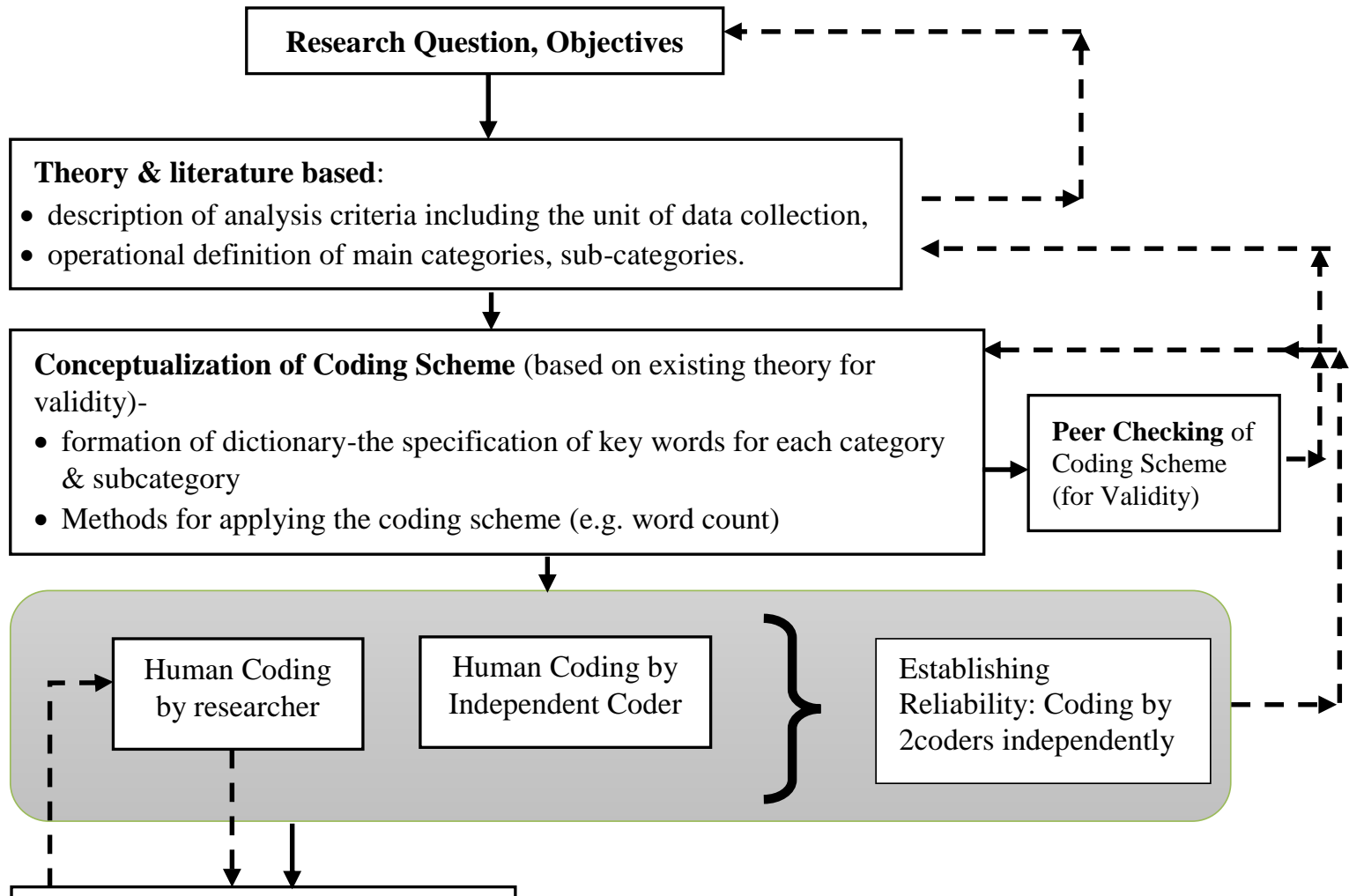

Comparison of results between the researcher and independent coder

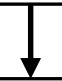

Tabulation and Interpretation of the results (e.g. through frequencies).

Note. Adapted from Neuendorf (2002).

\section{RESULTS AND DISCUSSION}

\subsection{Findings from Job Advertisements Analyses}

The data collected during eighteen weeks witnessed only thirty-six job advertisements where twenty-seven vacancies required bachelor's level qualification and nine required Masters in business related degrees. The vacancy advertisements were mostly called for mid-level positions (29 out of 36 vacant posts), the rest four positions were announced for senior level. The advertisements were announced by a wide range of industries. The highest proportion of vacancies came from the consumer goods industry, beverage industry, and health care sector respectively. Figure 3 compiles the type of organization announcing the vacancies. 


\section{Figure 3}

Representation of Industries Posting the Job Advertisements

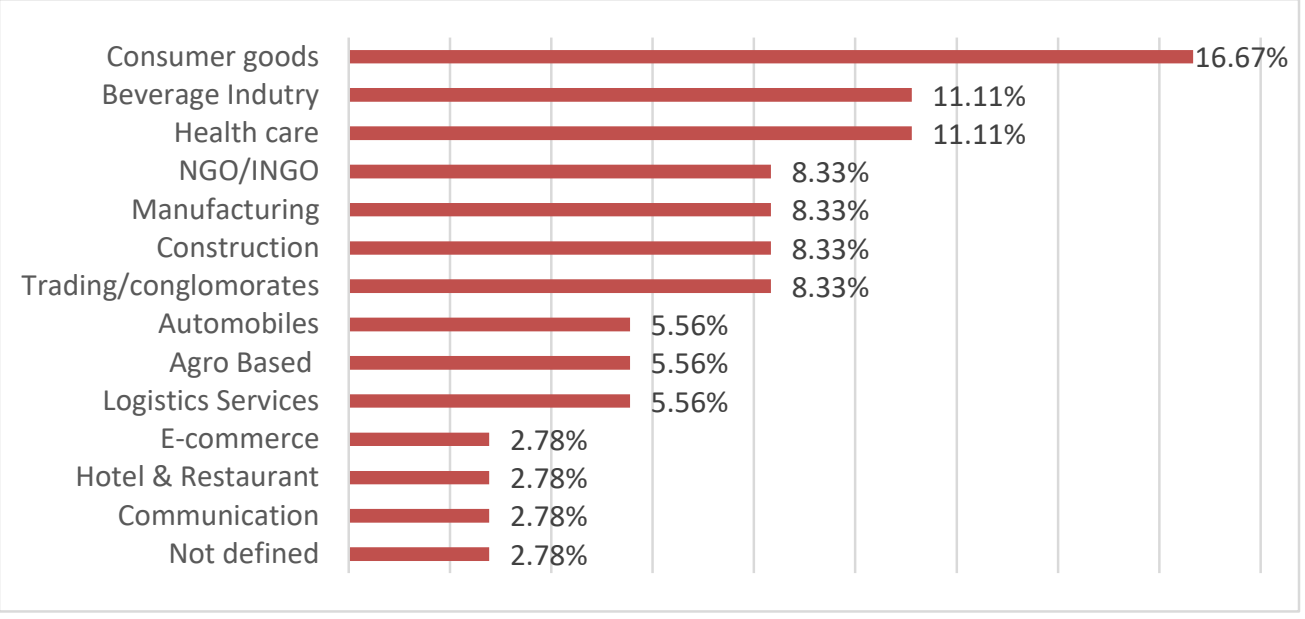

Leadership and team management skills were found to be the most commonly soughtafter skills by the Nepalese employers encompassing 29.6 percent of the requirements (Figure 4). Communication skills that include not only written and verbal skills but also presentation skills, report writing, and documentation skills, were the second most wanted skills among the graduates as job seekers with a figure of 19.3 percent. Employers in Nepal emphasized communication related skills that included verbal, written, and presentation.

\section{Table 4}

The proportion of Job Advertisements Indicating Different Skills

\begin{tabular}{lc}
\hline Skills category & Ads $(\%)$ \\
\hline Leadership \& team management & 29.6 \\
Communication & 19.3 \\
Basic IT \&computing skills & 15.6 \\
Other operations management skills & 9.6 \\
Negotiation & 8.1 \\
General analytical ability & 5.9 \\
Programming & 5.2 \\
Project related & 4.4 \\
Statistics & 2.2 \\
\hline Total & 100 \\
\hline
\end{tabular}

Next, 15.6 percent of the advertisements requested Basic IT and computing skills that required the eligible candidates to have skills to operate the computer and general office package software unaided. Operations-related managerial skills such as basic knowledge related to manufacturing, optimization, sourcing, storage, and supply-related activities were of medium requirements by the recruiters (only 9.6 percent). Likewise, other skills expected in the suitable candidates were the ability to analyze the situation and make appropriate decisions (5.9 percent), some programming related to database, programming in general or job-related software 
A Fit between Logistics and Supply Chain Management Education and Jobs Market Need in Nepal experiences (5.2\%), and the skills and knowledge to handle and lead the projects (4.4 percent). With a score of just 2.2 percent, statistical skills were the least required proficiency demanded by the employers.

Negotiation, the new category added to the existing category list developed by Sodhi et al. (2008), obtained an acceptable score of 8.1 percent, which might highlight the employer's importance attached with such skills. McCarter et al. (2005) identified it as one of the important skills for supply chain professionals. Likewise, Radovilsky and Hegde (2012) also found it as a growing important requirement in LSCM related vacancies. It would be worthwhile to mention that, unlike any other program, the MBA-GLM program offered by the School of Management, Tribhuvan University dedicated a 2-credit worth core course related to negotiation skills (GLM 533: Negotiation Skills for Global Business).

\subsection{Findings from the Analyses of LSCM Related Courses}

The textual information of all the syllabi collected from the selected universities were coded into quantitative data to derive a meaningful understanding regarding the coverage of logistics and supply chain management topics. Out of 34 business-related programs offered by the four universities in total, eleven of the programs offered a total of sixteen courses related to logistics and supply chain management including the seminar course as well.

\section{Table 5}

General Outline of the Course Nature and Credit Hours Allocated

\begin{tabular}{|c|c|c|c|c|c|c|c|}
\hline \multirow[b]{2}{*}{ Course title } & \multicolumn{4}{|c|}{ Course nature* } & \multicolumn{2}{|c|}{$\begin{array}{l}\text { Cr. } \\
\text { hrs. }\end{array}$} & \multirow[t]{2}{*}{ Program } \\
\hline & Co & $\mathrm{Cn}$ & El. & Sm. & 2 & 3 & \\
\hline \multicolumn{8}{|l|}{ Tribhuvan University } \\
\hline 1. GLM532: International Supply Chain Management & $\bullet$ & & & & $\bullet$ & & MBA-GLM \\
\hline 2. OPM511: Operations and Supply Chain Management & $\bullet$ & & & & & $\bullet$ & MBM \\
\hline 3. ISM205: Supply Chain Management & & $\bullet$ & & & & $\bullet$ & BBA \\
\hline 4. MKT215: Supply Chain and Channel Management & & $\bullet$ & & & & $\bullet$ & $\mathrm{BBM}$ \\
\hline $\begin{array}{l}\text { 5. IT229: IT Entrepreneurship and Supply Chain } \\
\text { Management }\end{array}$ & $\bullet$ & & & & & $\bullet$ & BIM \\
\hline \multicolumn{8}{|l|}{ Kathmandu University } \\
\hline 6. GEM 361: Supply Chain Management & & & $\bullet$ & & & $\bullet$ & BBA \\
\hline 7. GEM 361: Supply Chain Management & & & $\bullet$ & & & $\bullet$ & BBIS \\
\hline 8. MGEM 441: Strategic Supply Chain Management & & & $\bullet$ & & & $\bullet$ & BBA Hnrs. \\
\hline \multicolumn{8}{|l|}{ Purbanchal University } \\
\hline 9. PS531: Purchasing and Material Management & & $\bullet$ & & & & $\bullet$ & MBA \\
\hline 10. PS532: Designing and Managing the supply chain & & • & & & & $\bullet$ & MBA \\
\hline 11. PS544: Warehouse and Inventory Management & & $\bullet$ & & & & $\bullet$ & MBA \\
\hline 12. PS545 Facility Location Management & & $\bullet$ & & & & $\bullet$ & MBA \\
\hline 13. PS546: Network Design & & $\bullet$ & & & & $\bullet$ & MBA \\
\hline 14. PS547: Seminar on Production \& SCM & & & & $\bullet$ & & $\bullet$ & MBA \\
\hline 15. MGT171: Supply Chain Management & $\bullet$ & & & & $\bullet$ & & BBA \\
\hline \multicolumn{8}{|l|}{ Pokhara University } \\
\hline 16. MSC 626 Supply Chain and Global Operations & & $\bullet$ & & & $\bullet$ & & MBA \\
\hline
\end{tabular}

Note. Course nature*- Co. $=$ Core, Cn. $=$ Concentration, El. = Electives, Sm. =Seminar, hnrs. = Honors 
Tribhuvan University offered two courses at master's level and three courses at bachelor's level related to LSCM all of which belonged to either core or specialization courses. In Kathmandu University, three LSCM related courses-all as electives, were included in the curriculum of different bachelor-level programs. Purbanchal University was an exception as it had dedicated a separate full-fledged specialization option related to LSCM containing five different subjects in its MBA program. Likewise, one core course was allotted for its bachelor's program. Pokhara University did incorporate one LSCM related course as an elective in its MBA program. Table 5 depicts a general outline of the course nature and credit hours allocated.

Out of the sixteen courses offered related to LSCM, four of them were core courses, eight of them were concentrations while three of them were electives and one was a seminar course. In addition, the majority of the courses were of 3 credit hours (12 out of 16) while three of them were of two credit hours.

\subsection{Findings from the Comparison of Course Provisions and Job Requirements}

In an attempt to know the fit between the LSCM courses being delivered at the university level and the knowledge that the employers want to see in their potential job applicants, topics related to transportation and logistics, was the most that appealed to both the educators and employers as it amassed the highest proportion in comparison to other LSCM related topics. Inventory and Forecasting seemed to have a more or less similar focus of either party. But topics such as marketing and channel restructuring, sourcing and supplier management, reverse logistics, and green issues had less coverage in the university course content in comparison to the proportion demanded for such knowledge by the employers. However, topics related to location and supply chain design, information and electronic mediated environment, metrics and incentives, outsourcing, and strategic alliances were more of the focus in the course studies than required by the companies announcing the vacancies. Table 6 reveals much of the scenario about the comparison of course provisions and job requirements fit.

\section{Table 6}

Comparison of Course Provisions and Job Requirements

\begin{tabular}{lcc}
\hline \multicolumn{1}{c}{ Knowledge category } & $\begin{array}{c}\text { LSCM topics } \\
\text { coverage in } \\
\text { courses }(\%)\end{array}$ & $\begin{array}{c}\text { Job requirements } \\
\text { specified in } \\
\text { advertisements }(\%)\end{array}$ \\
\hline Location and supply chain design & 5.1 & 2.6 \\
Transportation and logistics & $\mathbf{3 4 . 2}$ & $\mathbf{2 7 . 9}$ \\
Inventory and forecasting & 15.3 & 13.7 \\
Marketing and channel restructuring & 9.5 & 15.3 \\
Sourcing and supplier management & 9.2 & 20.5 \\
Information and electronic mediated environment & 9.2 & 4.2 \\
Product design and new product introduction & 1.7 & 0.5 \\
Service and after sales support & 1.7 & 3.2 \\
Reverse logistics and green issues & 0.7 & 3.7 \\
Outsourcing and strategic alliances & 4.4 & 2.6 \\
Metrics and incentives & 8.1 & 4.2 \\
Global issues & 1 & 1.6 \\
\hline
\end{tabular}




\subsection{Discussion}

The study reveals that the inclusion of LSCM related courses in the business-related programs at Nepalese universities is very negligible as they were limited to just one course per program weighing not more than three credit hours; except Purbanchal University with a total of 32 credit hours. Something uncommon about Purbanchal University was that almost half of the permanent faculty members from its business school have their higher degrees in logistics services which could have enabled them to offer a full-fledge LSCM related specialization.

While considering the rest of the universities with such a small proportion of LSCM related courses, it can be readily assumed that LSCM is currently out of the focus of University teachings in Nepal. Instead, there seems to be an unprecedented number of business schools and colleges offering traditional business degrees such as BBA, MBA, BBS, and MBS. The reason could be the universally acceptable nature of these degrees for most types of management jobs and appears to be highly saleable programs to schools and colleges which might have overshadowed LSCM related programs or course offerings. The lack of adequate faculties with LSCM related degrees in Nepalese Universities could be another reason as studies from Lanconi et al. (2001b), Mangan and Christoper (2005), and Gravier and Farris (2008) outlined it as one of the most pressing factors that influence logistics education. In this regard, Lanconi et al. (2001a) concluded that there is a need for encouraging colleges and university administrations to support the LSCM programs.

This paper also teased out the relative importance of professional skills reckoned by the employers in their job advertisements. Skills that related to leadership and team management were most demanded by the employers. This is in line with previous studies that indicated the importance of team management skills (Gammerlgaard \& Larson, 2001; Sohal, 2013; Lutz \& Birou, 2013; Myers et al., 2004; Sodhi et al. 2008), and observed leadership as a very essential skill for an effective supply chain management by the studies of Sodhi et al. (2008), Sohal (2013), Lutz and Birou (2013) and Jordan and Bak, (2016).

An excellent proficiency over written and verbal communication skills and IT and computing skills were a frequent demand by the employers. The previous research by Gammelgaard and Larson (2001) also concluded communication is one of the most important skills for supply chain management employees while Giunipero et al. (2006) concluded it as one of the top five skills required for senior logistics and supply chain executives.

Finally, when comparing the relative coverage of LSCM topics by the educators to the relative demand for such knowledge by the employers, there seems to be an over-emphasis or under-emphasis of courses related to LSCM both at the bachelors and masters level. The study findings are similar to the findings from Sinha et al., (2016) and Sodhi et al., (2008).

\section{CONCLUSIONS}

It is the need of time that the educators devised their courses and programs in such a way that employers' demand for graduates with relevant knowledge and skills are adequately met. It has also been stressed by Wu et al. (2013) where they have emphasized the necessity of educators and practitioners working together to blur the gap between industry requirements and courses to adapt to the global environment. This way it will not only help employers to get a more suitable workforce but also help universities improve the employability of their graduates in the job market. The study findings shall help the educators to revise their course content to better fit the 
employers' needs and make their graduates more appropriate for the market. Scott et al., (2015) remind that the success of a business in the coming decades shall rest upon the companies' ability to ensure the supply chain talent.

It should be reckoned that the findings from this study are needed to be confirmed by further research with comprehensive inclusion of all the universities, not only native to Nepal, but also of colleges and institutes affiliated to foreign universities that may have offered programs or courses related to LSCM. Since the inherent limitations possessed by content analysis may have, otherwise, curtailed the scope of findings of this study, it is suggested that future research using different techniques such as questionnaires, surveys, focus group discussions or interviews could be conducted.

\section{ACKNOWLEDGEMENTS}

The authors are grateful to the Faculty Research Grant, School of Business - Pokhara University for funding this research. A special vote of thanks goes to Associate Professor Surya Bahadur G.C., Ph.D. for his wonderful research insights while carrying out this study.

\section{REFERENCES}

Bahouth, S., Hartmann, D., \& Willis, G. (2014). Supply chain management: How the curricula of the top ten undergraduate universities meet the practitioner's knowledge set. American Journal of Business Education (AJBE), 7(4), 285-289. https://doi.org/10.19030/ ajbe.v7i4.8817

Ballou, R. H. (2007). The evolution and future of logistics and supply chain management. European Business Review, 19(4) 332-348. https://doi.org/10.1108/ 09555340710760152

Cacciolatti, L., \& Molinero, C. M. (2013). Analysing the demand for supply chain jobs through job advertisements, Working Paper No. 264, Kent Business School, University of Kent, UK. https://kar.kent.ac.uk/33775/1/cacciolatti\%20mar\%20molinero\%20(2012)_ versioneintegrale $2 \% 20 \mathrm{Web} . p d f$

Onar, S. C., Aktas, E., Topcu, Y. I., \& Doran, D. (2013). An analysis of supply chain related graduate programmes in Europe. Supply Chain Management: An International Journal, 18(4), 398-412. https://doi.org/10.1108/SCM-06-2012-0209

Gammelgaard, B., \& Larson, P. (2001). Logistics skills and competencies for supply chain management. Journal of Business Logistics, 22(2), 27-50. https://doi.org/10.1002/j.21581592.2001.tb00002.x

Giunipero, L., Handfield, R. B., \& Eltantawy, R. (2006). Supply management's evolution: Key skill sets for the supply manager of the future. International Journal of Operations \& Production Management, 26(7), 822-844. https://doi.org/10.1108/01443570610672257

Gravier, M. J., \& Theodore, F. M. (2008). An analysis of logistics pedagogical literature: Past and future trends in curriculum, content, and pedagogy. The International Journal of Logistics Management, 19(2) 233-253. https://doi.org/10.1108/09574090810895979

Johnson, M. E., \& Pyke, D. F. (2000). A framework for teaching supply chain management. Production and Operations Management, 9(1), 2-18. https://doi.org/10.1111/j.19375956.2000.tb00319.x

Jordan, C., \& Bak, O. (2016). The growing scale and scope of the supply chain: A reflection on 
A Fit between Logistics and Supply Chain Management Education and Jobs Market Need in Nepal

supply chain graduate skills. Supply Chain Management, 21(5), 610-626. https://doi.org/ 10.1108/SCM- 02-2016-0059

Kovács, G., Tatham, P., \& Larson, P. D. (2012). What skills are needed to be a humanitarian logistician? Journal of Business Logistics, 33(3), 245-258. https://doi.org/10.1111/j.21581592.2012.01054.x

Krippendorff, K. (2004). Content analysis: An introduction to its methodology. Sage Publications. Lancioni, R., Forman, H., \& Smith, M.F. (2001a). Logistics programs in universities: Stovepipe vs. cross disciplinary. International Journal of Physical Distribution \& Logistics Management, 31(1), 53-64. https://doi.org/10.1108/09600030110366429

Lancioni, R., Forman, H., \& Smith, M. F. (2001b). Logistics and supply chain education: Roadblocks and challenges. International Journal of Physical Distribution \& Logistics Management, 31(10), 733-745. https://doi.org/10.1108/EUM0000000006287

Langley Jr, J. C., \& Mundy, R. A. (1978). Transportation/logistics curriculum evaluation: Academics versus industry representative responses. In the proceedings of A Workshop on Developing Logistics Programs edited by Richard A. Lancioni and Benjamin S. Blanchard. (Arlington, Va.: Society of Logistics Engineers and the Virginia Poly Technical Institute and State University.

Lutz, H., \& Birou, L. (2013). Logistics education: A look at the current state of the art and science. Supply Chain Management, 18(4), 455-467. http://doi.org/10.1108/SCM-082012-0269.

Mangan, J., \& Christopher, M. (2005). Management development and the supply chain manager of the future. International Journal of Logistics Management, 16(2), 178- 191. https://doi.org/10.1108/09574090510634494

McCarter, M. W., Fawcett, S. E., \& Mangan, J. (2005). The effect of people on the supply chain world: Some overlooked issues. Human Systems Management, 24(3). 197- 208. https://doi.org/10.3233/HSM-2005-24302

Murphy, P. R., \& Poist, R. F. (1994). Educational strategies for succeeding in logistics: A comparative analysis. Transportation Journal, 33(3). 36-48. http://www/jstor.org/stable/20713204

Murphy, P. R., \& Poist, R. F. (1998). Skill requirements of senior-level logisticians: Practitioner perspectives. International Journal of Physical Distribution \& Logistics Management, 28(4). 284-301. https://doi.org/10.1108/09600039110004025

Murphy, P. R., \& Poist, R. F. (2007). Skill requirements of senior-level logisticians: A longitudinal assessment. Supply Chain Management, 12(6), 423-431. https://doi.org/10.1108/13598540710826353

Myers, M. B., Griffith, D. A., Daugherty, P. J., \& Lusch, R. F. (2004). Maximizing the human capital equation in logistics: Education, experience, and skills, Journal of Business Logistics, 25(1), 211-32. https://doi.org/10.1002/j.2158-1592.2004.tb00175.x

Neuendorf, K. A. (2002). The content analysis guidebook. Sage Publications.

Potter, W. J., \& Levine-Donnerstein, D. (1999). Rethinking validity and reliability in content analysis. Journal of Applied Communication Research, 27(3), 258-284. https://doi.org/ 10.1080/00909889909365539

Radovilsky, Z., Hegde, V. G., \& Kandasamy, G. (2007). Development of supply chain management through job market requirements. California Journal of Operations Management, 5(1), 52-59.

Radovilsky, Z., \& Hegde, V. (2012). Trends in supply chain management job requirements: A 
longitudinal study. Journal of Supply Chain and Operations Management, 10(1), 168-181.

Scott, S., Burnett, M., Dittman, P., Stank, T., \& Autry, C. (2015). Supply chain talent: Our most important resource. Knoxville, TN: University of Tennessee, Global Supply Chain Institute. https://haslam.utk.edu/sites/default/files/Talent_paperFINAL.pdf

Sinha, A., Millhiser, W., \& He, Y. (2016). Matching supply with demand in supply chain management education. International Journal of Logistics Management, 27(3) 837-861. https://doi.org/10.1108/IJLM-03-2015-0058

Sodhi, M. S., Son, B. G., \& Tang, C. S. (2008). ASP, the art and science of practice: What employers demand from applicants for MBA-level supply chain jobs and the coverage of supply chain topics in MBA courses. Interfaces, 38(6), 469-484. https://doi.org/ 10.1287/inte. 1080.0377

Sohal, A. S. (2013). Developing competencies of supply chain professionals in Australia: Collaboration between businesses, universities and industry associations. Supply Chain Management, 18(4), 429-439. https://doi.org/10.1108/SCM-07-2012-0228

Van Hoek, R. I., Chatham, R., \& Wilding, R. (2002). Managers in supply chain management, the critical dimension. Supply Chain Management: An International Journal, 7(3), 119125.https://doi.org/10.1108/13598540210436568

Wu, J. Y. (2007). Contemporary logistics education: An international perspective. International Journal of Physical Distribution \& Logistics Management, 37 (7), 504-528. http://doi.org/ 10.1108/09600030710776455

Wu, Y. J., Huang, S. K., Goh, M., \& Hsieh, Y. (2013). Global logistics management curriculum: Perspective from practitioners in Taiwan. Supply Chain Management: An International Journal, 18(4), 376-388. https://doi.org/10.1108/SCM-04-2012-0145 